\title{
Effect of Low Temperatures on the Mechanical Properties of a Commercially Pure Titanium ${ }^{1}$
}

\author{
Glenn W. Geil and Nesbit L. Carwile
}

\begin{abstract}
Notehed and unnotched tensile specimens of annealed commercially pure titanium were slowly strained to fracture in single-stage tests at $-196^{\circ}$ to $+100^{\circ} \mathrm{C}$. Unnotched tensile specimens also were strained in two-stage tests (strained at one temperature until just after the maximum load was reached and then strained to fracture at a different temperature) to reveal the effect of prior-strain-temperature history on the tensile properties of the titanium. Impact tests were made on Charpy $V$-noteh specimens at $-196^{\circ}$ to $+200^{\circ} \mathrm{C}$ for a determination of the impact notch-toughness of the metal. True-stress-true-strain relations were determined for the titanium in tension, and a study was made of the effects of test temperature and the stress distribution on the rates of work-hardening of the metal.
\end{abstract}

\section{Introduction}

A study of some of the mechanical properties of one heat of annealed commercially pure titanium has been made as a part of a comprehensive program to evaluate the fundamental factors affecting the deformation of metals. This study was made to determine the effect of low temperatures on the tensile and impact properties and the true-stresstrue-strain relations for this metal in tension. The experimental program included tests as follows: (1) Single-stage tension tests on both notched and unnotched specimens of circular cross section at $-196^{\circ}$ to $+100^{\circ} \mathrm{C}$, (2) two-stage tension tests on unnotched specimens (specimens strained at one temperature until just after the maximum load was reached and then strained to fracture at a different temperature) and (3) impact tests on Charpy V-notch specimens at $-196^{\circ}$ to $+300^{\circ} \mathrm{C}$.

Published data on the tensile properties and the true-stress-true-strain relations for titanium in tension at low temperatures are very limited. Spretnak, Fontana, and Brooks $[1]^{2}$ and Fontana, Bishop, and Spretnak [2] reported an increase in the strength of hot-swaged titanium (chemical composition was not reported), accompanied by a general decrease in elongation and reduction of area as the test temperature was decreased within the range $+25^{\circ}$ to $-253^{\circ}$ C. Rosi and Perkins [3], in a study of some of the tensile properties and strain-aging characteristics of a heat of annealed commercially pure titanium at $-196^{\circ}$ to $+652^{\circ} \mathrm{C}$, also observed a general trend of a decrease in ductility (elongation and reduction of area values) with decrease in test temperature.

\section{Material and Test Procedures}

\subsection{Material}

All test specimens were prepared from three bars processed from the same heat of commercially pure

1 This study was made possible by transfer funds made available by the Department of the Army, Ordnance Corps, through Watertown Arsenal.

2 Figures in brackets indicate the literature references at the end of this paper. titanium (ASTM Designation B265-52T, grade 2). The bars were supplied in the form of $5 / 8$-in. rounds in the hot-rolled and annealed condition; the bars were fine grained (fig. 1). The impurities (numerical values are in percent by weight) determined ${ }^{3}$ in the titanium were as follows: Oxygen, 0.07 ; nitrogen, 0.02 ; hydrogen, 0.0065 ; carbon, 0.02 ; silicon, 0.02 ; iron, M; manganese, V. W.; tin, W; copper, T; nickel, V.W.; tungsten, not determined. ${ }^{4}$

\subsection{Specimens}

Each unnotched tensile specimen had a 2-in. gage length and a diameter of $0.40 \mathrm{in}$. at the midsection of the gage length. The reduced section was slightly tapered, so that the diameter was about $0.003 \mathrm{in}$. greater at the ends of the gage length. The specimens were finished to the final dimensions by grinding and polishing in the axial direction to eliminate the possibility of any circumferential tool marks. The ends of the specimens were machined with $5 / 8$ in. $\times 11$ threads, and the shoulder fillets were machined to a radius of 0.75 in.

Each notched tensile specimen, on the other hand, had a 2 -in. reduced section of 0.45 -in. diameter and a circumferential $V$-notch of 60-degree angle and 0.01 -in. root radius at the midpoint of the reduced section. One series of notched specimens was prepared with relatively shallow notches of 0.025 -in. depth (minimum diameter of specimen at root of notch equal to $0.400 \mathrm{in}$.). A second series of notched specimens was prepared with relatively deep notches of 0.125 -in. depth (minimum diameter of specimen at root of notch equal to $0.200 \mathrm{in}$.).

For the impact tests, standard Charpy V-notch specimens were prepared from one of the $5 / 8-i n .-$ diameter bars. ${ }^{3}$ Chemical-analysis determinations for nitrogen, carbon, and silicon were made
by the Analytical Chemistry Section of the NBS. Vacuum-fusion determinations for oxygen and hydrogen were made at the Naval Research Laboratory by the method developed by D. I. Walter [4]. The spectrographic-analysis determinations for iron, manganese tin copper, and nickel were made by the determinations for chemistry section of the NBS. In general, M denotes moderate $(0.1$ to $1.0 \%)$ W denotes weak $(0.01$ to $0.1 \%)$.

$\mathrm{T}$ denotes trace $(0.0001$ to $0.001 \%)$. 4 The spectrographic method used was not sensitive enough for determination
of tungsten. 

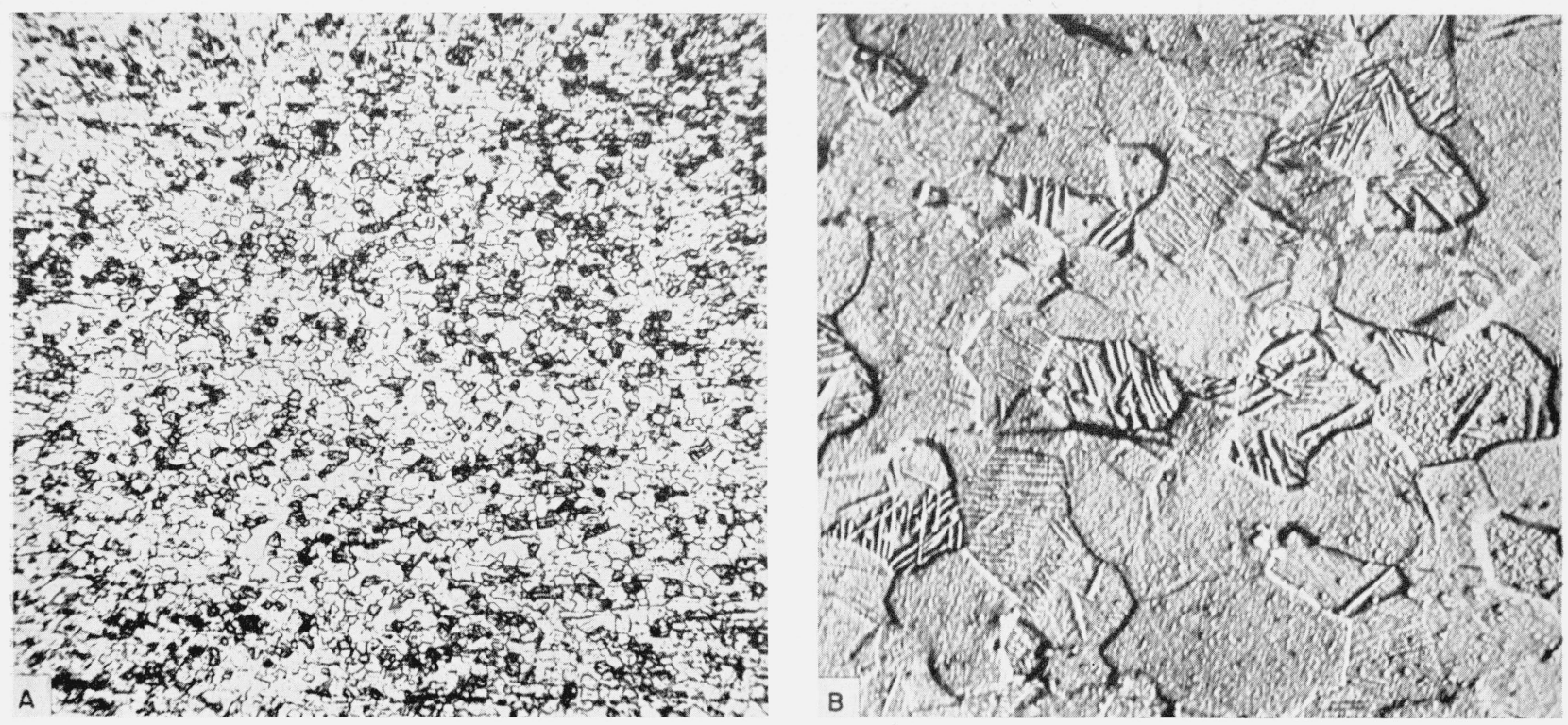

FIGURE 1. Microstructure of annealed commercially pure titanium.

Longitudinal sections. Etchant: 1 part of $\mathrm{HF}, 10$ parts of $\mathrm{HCl}, 10$ parts of $\mathrm{HNO}_{3}, 80$ parts of water. $A, \times 100$, vertical illumination. $B, \times 1,000$, oblique illumination (left to right).

\subsection{Methods}

In the single-stage tension tests at $-196^{\circ}$ to $+100^{\circ} \mathrm{C}$, with notched and unnotched specimens, the specimens were extended slowly with the deformation rate maintained at about 0.5 - to 1.0 -percent reduction in area per minute during the deformation beyond initial yielding. The specimens, except those tested at room termperature, were extended to fracture while completely immersed in an appropriate cryogenic bath maintained at the selected temperature. The specimens were immersed in the bath for a period of $30 \mathrm{~min}$ prior to the application of load. The minimum diameter of the specimen was measured to an accuracy of 0.0001 in. during the test by means of a specially designed gage [5]. Simultaneous load and diameter measurements were made throughout each tension test. A detailed description of the testing equipment and the method of maintaining the selected temperature is given in previous publications $[5,6]$.

In the two-stage tension tests, the unnotched tensile specimen was strained at one temperature until just after the maximum load was reached and then strained to fracture at a different temperature. Between the two stages of the test, the load was removed and the specimen was maintained at the lower of the two testing temperatures in order to minimize any strain-aging that might occur during this period. The second stage of the test was begun approximately $30 \mathrm{~min}$ after completion of the first stage. The rest of the test procedure was the same as that for the single-stage tests.

The notched-bar impact tests were carried out at $-196^{\circ}$ to $+300^{\circ} \mathrm{C}$ in a Charpy machine of 224.1 $\mathrm{ft}-\mathrm{lb}$ capacity with a striking velocity of $16.85 \mathrm{ft} / \mathrm{sec}$. The specimens, except the ones tested at $+26^{\circ} \mathrm{C}$, were immersed in a bath at the desired temperature for a minimum period of $30 \mathrm{~min}$ and then quickly transferred to the impact machine and broken. The total time elapsing between the removal from the bath and the breaking of the specimen ranged from about 3 to 4 sec, and there was no significant change in the temperature of the specimen.

\section{Results and Discussion}

\subsection{Tensile Data}

Some of the tensile properties of this heat of commercially pure titanium, as determined on both notched and unnotched specimens deformed slowly in tension at $-196^{\circ}$ to $+100^{\circ} \mathrm{C}$, are given in table 1 .

No yield points were observed in any of the tension tests. Determinations of yield strength based on 0.1 - or 0.2-percent offset values were not made because the data for stress-strain curves could not be obtained directly with the testing equipment. However, an approximation of the yield strength of the specimens at the different temperatures is given in table 1 as the true stress at a true strain ${ }^{5}$ (elastic plus plastic) of 0.01 .

The true-stress, true-strain, and reduction-in-area values at the initiation of fracture reported in table 1 were determined from the load and diameter readings obtained during the test. The values of reduction of area, determined from measurements made on the unnotched tensile specimens after complete fracture, are not significantly different from reduction-in-area values for the initiation of the facture. These data

\footnotetext{
True stress was determined by dividing the current load by the current minimum cross-sectional area of the specimen. The true strain was determined a the natural logarithm of the ratio of the original cross-sectional area of the specimen, $A_{0}$, to the current minimum cross-sectional area, $A$.
} 
TABLE 1. Tensile properties of annealed commercially pure titanium at different temperatures

\begin{tabular}{|c|c|c|c|c|c|c|c|c|c|c|c|c|}
\hline \multirow{2}{*}{ Specimen designation } & \multirow{2}{*}{ Bar } & \multirow{2}{*}{$\begin{array}{l}\text { Temper- } \\
\text { ature }\end{array}$} & \multirow{2}{*}{$\begin{array}{c}\text { Tensile } \\
\text { strength }\end{array}$} & \multicolumn{3}{|c|}{ True stress at- } & \multicolumn{2}{|c|}{ True strain at- } & \multicolumn{2}{|c|}{$\begin{array}{c}\text { Reduction in area } \\
\text { at }-\end{array}$} & \multirow{2}{*}{$\begin{array}{l}\text { Reduc- } \\
\text { tion of } \\
\text { area }\end{array}$} & \multirow{2}{*}{$\begin{array}{l}\text { Elonga- } \\
\text { tion in } \\
2 \mathrm{in.}\end{array}$} \\
\hline & & & & $\begin{array}{l}\text { True } \\
\text { strain } \\
\text { of } 0.01\end{array}$ & $\begin{array}{l}\text { Maxi- } \\
\text { mum } \\
\text { load }\end{array}$ & $\begin{array}{c}\text { Initial } \\
\text { fracture }\end{array}$ & $\begin{array}{l}\text { Maxi- } \\
\text { mum } \\
\text { load }\end{array}$ & $\begin{array}{l}\text { Initial } \\
\text { fracture }\end{array}$ & $\begin{array}{l}\text { Maxi- } \\
\text { mum } \\
\text { load }\end{array}$ & $\begin{array}{c}\text { Initial } \\
\text { fracture }\end{array}$ & & \\
\hline \multicolumn{13}{|c|}{ Unnotched tensile specimens (single-stage tests and first stage of two-stage tests) } \\
\hline Ti-8. & A & $\begin{array}{l}\circ C \\
+100\end{array}$ & $\begin{array}{c}l b / \text { in }^{2} \\
65,000\end{array}$ & $\begin{array}{c}l b / \text { in }^{2} \\
54,000\end{array}$ & $\begin{array}{c}l b / \text { in }^{2} \\
73,000\end{array}$ & $\begin{array}{l}l b / \text { in }^{2} \\
101,000\end{array}$ & 0.119 & 0.616 & $\begin{array}{l}\% \\
11\end{array}$ & $\begin{array}{l}\% \\
46\end{array}$ & $\%$ & $\begin{array}{l}\% \\
23\end{array}$ \\
\hline $\begin{array}{l}\text { Ti-1 } \\
\text { Ti-9.2. } \\
\text { Ti-37 } \\
\text { Ti-5 a }\end{array}$ & $\begin{array}{l}\mathrm{A} \\
\mathrm{B} \\
\mathrm{C} \\
\mathrm{A}\end{array}$ & $\begin{array}{l}+26 \\
+24 \\
+21 \\
+24\end{array}$ & $\begin{array}{l}77,000 \\
79,000 \\
79,000 \\
80,000\end{array}$ & \begin{tabular}{l|}
64.000 \\
63,000 \\
66,000 \\
62,000
\end{tabular} & $\begin{array}{l}92,000 \\
89,000 \\
90,000 \\
93,000\end{array}$ & $\begin{array}{c}131,000 \\
128,000 \\
125,000 \\
-\end{array}$ & $\begin{array}{r}0.174 \\
.119 \\
.134 \\
.148\end{array}$ & $\begin{array}{r}0.699 \\
.688 \\
.664 \\
\end{array}$ & $\begin{array}{l}16 \\
11 \\
13 \\
14\end{array}$ & $\begin{array}{r}50 \\
50 \\
49 \\
\end{array}$ & $\begin{array}{c}50 \\
50 \\
50 \\
\end{array}$ & $\begin{array}{l}19 \\
24 \\
23 \\
\end{array}$ \\
\hline Average _. & -...- & +24 & 79,000 & 64,000 & 91,000 & 128,000 & 0.144 & 0.684 & 13 & 50 & 50 & 22 \\
\hline $\begin{array}{l}\text { Ti-2 } \\
\text { Ti-38 b. }\end{array}$ & $\stackrel{\mathrm{A}}{\mathrm{C}}$ & $\begin{array}{l}-78 \\
-78\end{array}$ & $\begin{array}{r}101,000 \\
99,000\end{array}$ & $\begin{array}{l}85,000 \\
83,000\end{array}$ & $\begin{array}{l}116,000 \\
114,000\end{array}$ & 167,000 & $\begin{array}{r}0.140 \\
.136\end{array}$ & 0.701 & $\begin{array}{l}13 \\
13\end{array}$ & 50 & $\begin{array}{c}50 \\
\end{array}$ & 19 \\
\hline A verage.. & -...-- & -78 & 100,000 & 84,000 & 115,000 & -....... & 0.138 & 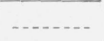 & 13 & 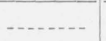 & - & ...... \\
\hline Ti-4_. & A & -150 & 117,000 & 101,000 & 144,000 & 235,000 & 0.208 & 0.876 & 19 & 58 & 58 & 27 \\
\hline $\begin{array}{l}\text { Ti-3 } \\
\text { Ti-6 } 6 \ldots \\
\text { Ti-10 } \\
\text { Ti-7 }{ }^{\text {e }} \ldots\end{array}$ & $\begin{array}{l}\mathrm{A} \\
\mathrm{A} \\
\mathrm{B} \\
\mathrm{A}\end{array}$ & $\begin{array}{l}-196 \\
-196 \\
-196 \\
-196\end{array}$ & $\begin{array}{l}144,000 \\
142,000 \\
145,000 \\
146,000\end{array}$ & $\begin{array}{l}117,000 \\
117,000 \\
117,000 \\
118,000\end{array}$ & $\begin{array}{l}217,000 \\
208,000 \\
216,000 \\
218,000\end{array}$ & \begin{tabular}{c}
275,000 \\
274,000 \\
\hdashline$\cdots$
\end{tabular} & $\begin{array}{r}0.412 \\
.374 \\
.401 \\
.406\end{array}$ & $\begin{array}{r}0.773 \\
.800 \\
\end{array}$ & $\begin{array}{l}34 \\
31 \\
33 \\
33\end{array}$ & $\begin{array}{c}54 \\
55 \\
-\end{array}$ & $\begin{array}{c}55 \\
56 \\
-1\end{array}$ & $\begin{array}{l}41 \\
41 \\
- \\
-\end{array}$ \\
\hline A verage _. & ...... & -196 & 144,000 & 117,000 & 215,000 & 274,000 & 0.398 & 0.786 & 33 & 54 & 55 & 41 \\
\hline \multicolumn{13}{|c|}{ Unnotched tensile specimens (second-stage of two-stage tests d) } \\
\hline $\begin{array}{l}\text { Ti-5 a } \\
\text { Ti-38 }{ }^{\text {b }} \\
\text { Ti-7 }{ }^{\circ} \ldots\end{array}$ & $\begin{array}{l}\mathrm{A} \\
\mathrm{C} \\
\mathrm{A}\end{array}$ & $\begin{array}{l}-196 \\
+24 \\
+24\end{array}$ & $\mid$\begin{tabular}{l}
$\mid$ \\
\hdashline
\end{tabular} & (n..... & $\begin{array}{r}218,000 \\
92,000 \\
138,000\end{array}$ & $\begin{array}{l}289,000 \\
119,000 \\
170,000\end{array}$ & $\begin{array}{r}0.473 \\
.168 \\
.500\end{array}$ & $\begin{array}{r}0.920 \\
.630 \\
1.073\end{array}$ & $\begin{array}{l}38 \\
15 \\
39\end{array}$ & $\begin{array}{l}40 \\
47 \\
66\end{array}$ & $\begin{array}{l}40 \\
50 \\
66\end{array}$ & 37 \\
\hline \multicolumn{13}{|c|}{ Notched tensile specimens (shallow notches, 0.025 -in. depth) } \\
\hline $\begin{array}{l}\text { Ti-30_.. } \\
\text { Ti-31_.. } \\
\text { Ti-28 } \\
\text { Ti-29... }\end{array}$ & $\begin{array}{l}\mathrm{C} \\
\mathrm{C} \\
\mathrm{C} \\
\mathrm{C}\end{array}$ & $\begin{array}{r}+100 \\
+24 \\
-78 \\
-196\end{array}$ & $\begin{array}{r}76,000 \\
94,000 \\
113,000 \\
149,000\end{array}$ & $\begin{array}{r}48,000 \\
47,000 \\
89,000 \\
118,000\end{array}$ & $\begin{array}{r}91,000 \\
109,000 \\
127,000 \\
164,000\end{array}$ & $\begin{array}{r}96,000 \\
112,000 \\
127,000 \\
164,000\end{array}$ & $\begin{array}{r}0.183 \\
.151 \\
.115 \\
.094\end{array}$ & $\begin{array}{r}0.275 \\
.184 \\
.115 \\
.097\end{array}$ & $\begin{array}{r}17 \\
14 \\
11 \\
9\end{array}$ & $\begin{array}{r}25 \\
17 \\
11 \\
9\end{array}$ & (n) & - \\
\hline \multicolumn{13}{|c|}{ Notched tensile specimens (deep notches, 0.125-in. depth) } \\
\hline $\begin{array}{l}\text { Ti-35 } \\
\text { Ti-36.... } \\
\text { Ti-33 } \\
\text { Ti-34 }\end{array}$ & $\begin{array}{l}\mathrm{C} \\
\mathrm{C} \\
\mathrm{C} \\
\mathrm{C}\end{array}$ & $\begin{array}{r}+100 \\
+24 \\
-78 \\
-196\end{array}$ & $\begin{array}{l}112,000 \\
137,000 \\
168,000 \\
231,000\end{array}$ & $\begin{array}{r}45,000 \\
33,000 \\
95,000 \\
128,000\end{array}$ & $\begin{array}{l}130,000 \\
163,000 \\
195,000 \\
258,000\end{array}$ & $\begin{array}{l}138,000 \\
170,000 \\
200,000 \\
258,000\end{array}$ & $\begin{array}{r}0.151 \\
.178 \\
.148 \\
.110\end{array}$ & $\begin{array}{r}0.279 \\
.237 \\
.184 \\
.110\end{array}$ & $\begin{array}{l}14 \\
16 \\
14 \\
10\end{array}$ & $\begin{array}{l}24 \\
21 \\
17 \\
10\end{array}$ & - & - \\
\hline
\end{tabular}

a Specimen extended to a true strain of 0.149 (reduction in area $14 \%$ ) in first stage of test at $+24^{\circ} \mathrm{C}$.

Specimen extended to a true strain of 0.148 (reduction in area $14 \%$ ) in first stage of test at $-78^{\circ} \mathrm{C}$.

c Specimen extended to a true strain of 0.450 (reduction in area $36 \%$ ) in first stage of test at -
d Ductility values based on diameters of specimens prior to deformation in first stage of test.

indicate that the metal at the periphery of the necked section did not extend longitudinally or contract radially to any appreciable extent, as the fracture crack propagated rapidly from the axis to the periphery of the specimen.

Reduction-of-area values are not reported for the tension tests on notched specimens as measurements of the minimum diameter of the notched specimens after complete fracture could not be made with sufficient accuracy to warrant presentation. Moreover, as the ductility of the titanium is reduced when subjected to test conditions of multiaxial stresses and stress concentrations and gradients, such as those induced by the geometry of the notch, any contraction of the specimen during the rapid propagation of the fracture crack apparently would be negligible. Thus, it is believed that the reduction-in-area values for the notched specimens at the initiation of fracture and at complete fracture are approximately equal.

\subsection{Tensile Tests on Unnotched Specimens}

\section{a. True-Stress-True-Strain Relations and Work-Hardening Characteristics}

Representative true-stress-true-strain relations obtained for single-stage tension, tests on unnotched specimens at $-196^{\circ},-150^{\circ},-78^{\circ},+24^{\circ}$ and $+100^{\circ} \mathrm{C}$ are presented in figure 2. As the stress pattern across the necked section of a specimen is not uniform but varies considerably from the axis to the periphery, the true-stress values beyond the maximum load are only average values of the axial tensile stresses. No significant variations in the tensile properties were observed for the specimens prepared from the three different bars and tested at the same selected temperature $\left(+24^{\circ} \mathrm{C}\right)$. The true-stresstrue-strain values obtained on the different specimens show only a slight deviation from the curve representing the average values. The influence of temperature on the true-stress-true-strain relationship 


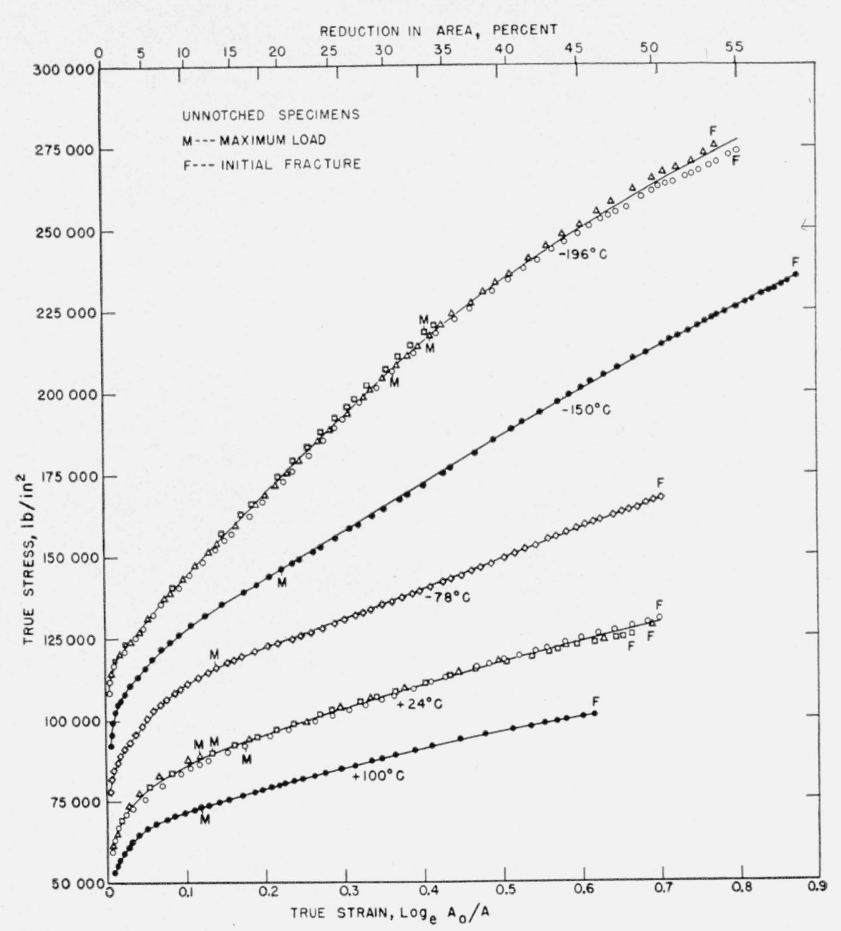

Figure 2. True-stress-true-strain graphs for tension tests made at various temperatures on unnotched specimens of the titanium.

The three specimens deformed at $+24^{\circ} \mathrm{C}$ were prepared from three different bars A, B, and C (table 1). All of the other specimens were prepared from bar A.

is relatively large for the commercially pure titanium, as evidenced by the increase in the height of the curve as the temperature is lowered. The initial resistance of the metal to plastic flow is increased greatly with decrease in temperature, being more than twice as great at $-196^{\circ} \mathrm{C}$ as at $+100^{\circ} \mathrm{C}$. Moreover, the rate of work-hardening ${ }^{6}$ of the titanium generally increases with decrease in the temperature.

It has often been postulated that the relationship between true stress and true strain for metals deformed in tension may be represented by $\sigma=b \delta^{m}$, in which $b$ and $m$ are constants characteristic of the material. The exponent $m$ is generally designated as the strain-hardening exponent. According to this relationship, the true-stress-true-strain data plotted to logarithmic scales should conform to a straight line drawn through the maximum-load point, with the slope of the line equal to $m$, which is also equal to the true strain at maximum load.

Logarithmic graphs of the true-stress-true-strain data for some of the tension tests made on unnotched specimens of the annealed commercially pure titanium are shown in figure 3 . The curves, in general, are sigmodial in shape. The data do not conform to the broken straight lines drawn through the maximum-load points with slopes equal to the true

\footnotetext{
${ }^{6}$ Work-hardening was determined as the increase in true stress, $\sigma$, with true strain, $\delta$. If strain-aging or recovery occurs during the tension test, the workhardening is the combined effect of these factors and the ordinary strain-hardening, and for strains beyond that at the maximum load, the effect of the induced triaxial stress system. The rate of work-hardening, $d \sigma / d \delta$, at any strain is the slope of the true-stress-true-strain curve at that strain.
}

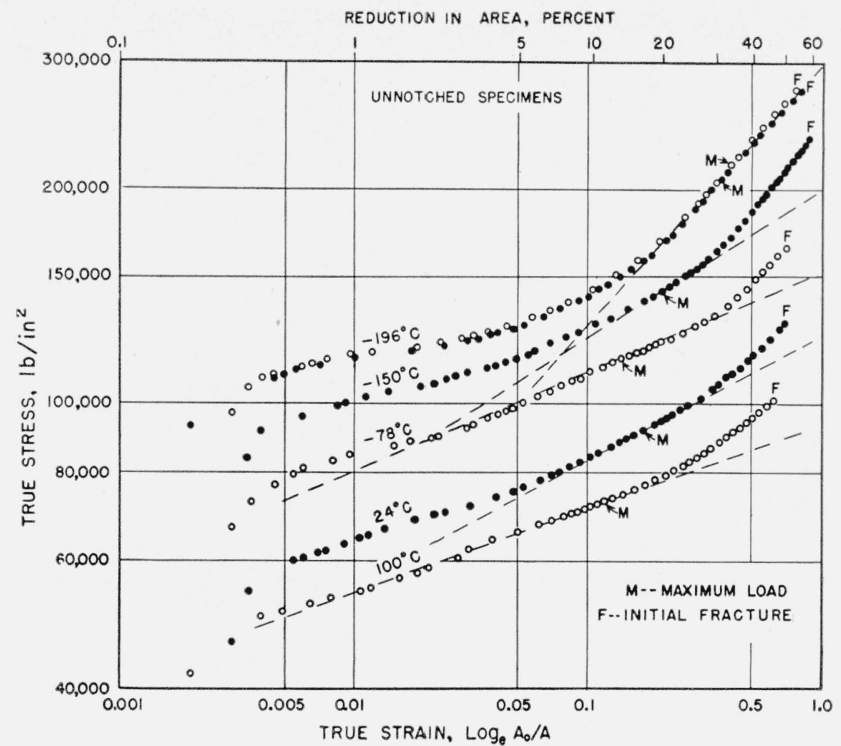

FIGURE 3. Logarithmic true-stress-true-strain graphs for tension tests made at various temperatures on unnotched specimens of the titanium.

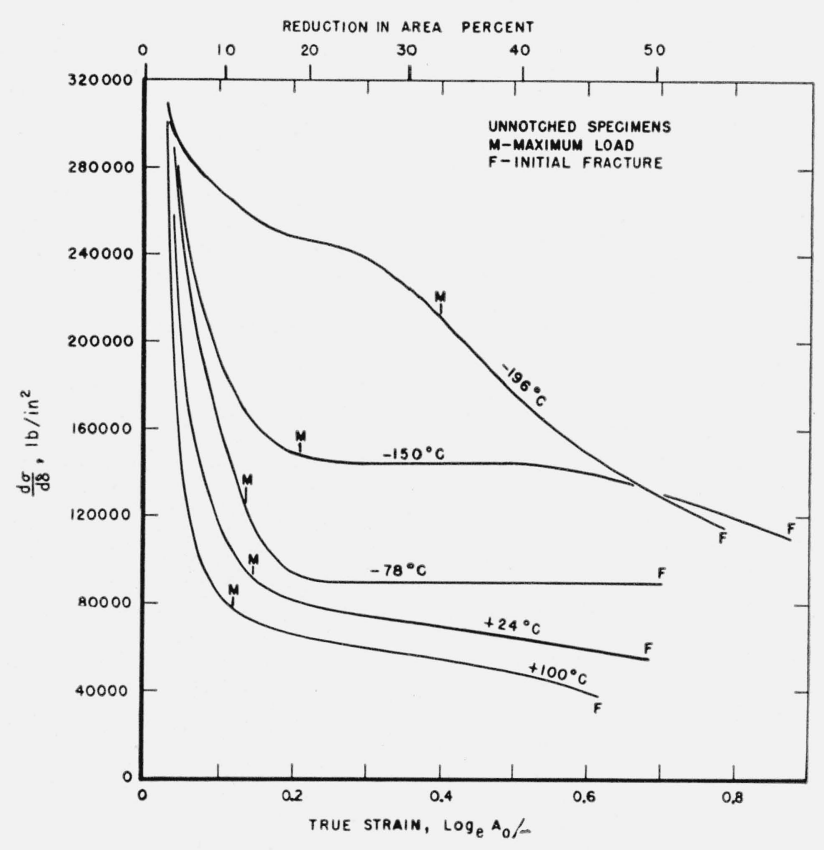

FIGURE 4. Variaticn of the rate of work-hardening with true strain, in tension tests made at various temperatures on unnotched specimens of the titanium.

strains at maximum load. Thus, no truly representative values for strain-hardening exponents, such as $m$ of the above equation, can be established from these data. Similar results, also indicating nonconformity to this relationship, were obtained in tests on other metals $[6,7]$.

The variations in the rate of work-hardening of the unnotched specimens of titanium with true strain at $-196^{\circ},-150^{\circ},-78^{\circ},+24^{\circ}$, and $+100^{\circ} \mathrm{C}$ are summarized in figure 4 . At small true strains $(0.02$ 


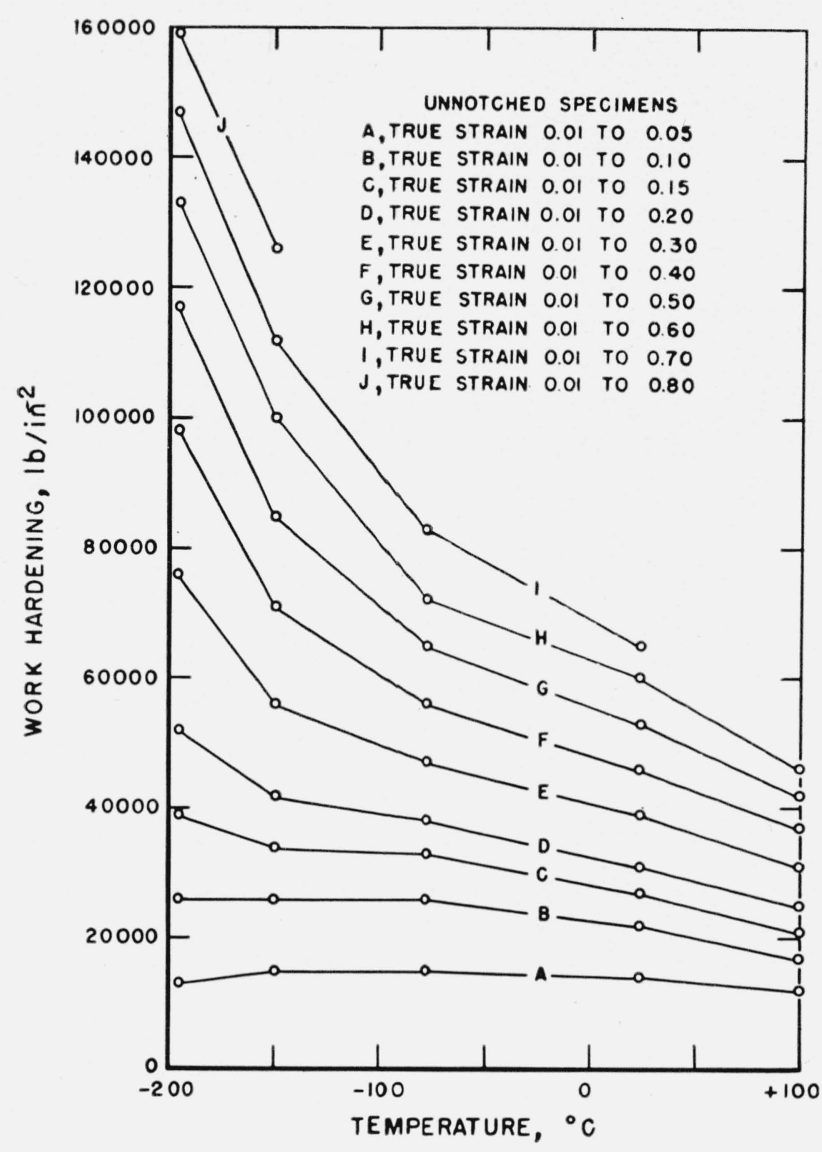

FIGURE 5. Influence of true strain on the relationship between the work-hardening and temperature of unnotched specimens of the titanium.

to 0.03 ) the rates of work-hardening of the specimens deformed at different temperatures were about the same. In general, the rate of work-hardening of the metal decreased with increase in true strain. The rapidity of this decrease, for loads up to the maximum, was much less at $-196^{\circ} \mathrm{C}$ than at higher temperatures. However, the decrease in the rate of work-hardening with increase in the true strain beyond that at maximum load was much greater for the specimens extended at $-196^{\circ} \mathrm{C}$ than for those extended at higher temperatures. The reversals in the curves at a true strain of approximately 0.2 for the specimens extended at $-196^{\circ} \mathrm{C}$ and approximately 0.4 for the specimen at $-150^{\circ} \mathrm{C}$ are indicative of the occurrence of a different mechanism of deformation or a phase change accompanying the plastic deformation.

In general, the rate of work-hardening increased with decrease in temperature except for small true strains, such as 0.03 . At the relatively small true strain of 0.03 , the rate of work-hardening was high (approximately, 300,000 lb/in. ${ }^{2}$ ) and was apparently independent of the testing temperature. With increase in true strain above 0.03 to fracture, the rate of work-hardening was highly dependent upon the temperature; at corresponding true strains of 0.1 and greater, the rates of work-hardening of specimens deformed at $-196^{\circ} \mathrm{C}$ were about three and one-half times as great as those of the specimen deformed at $+100^{\circ}$ C. However, no simple quantitative relationship was observed between the rate of workhardening at corresponding true strains and the temperature of deformation.

The relations between temperature and the workhardening accompanying the deformation of the unnotched specimens from a true strain of 0.01 to selected true strains ranging from 0.05 to 0.8 , are depicted in figure 5. Curve $\mathrm{A}$ for a small deformation, true strain 0.01 to 0.05 , shows no significant dependence of the work-hardening on temperature. However, with further increase in true strain, curves $\mathrm{B}$ to $\mathrm{J}$, the work-hardening is dependent upon the temperature. During deformation from a true strain of 0.01 to 0.6 (curve $\mathrm{H}$ ) it is nearly three times as great at $-196^{\circ} \mathrm{C}$ as at $+100^{\circ} \mathrm{C}$.

\section{b. Influence of Temperature on Tensile Properties}

The influence of temperature on the tensile strength and the true stresses at a true strain of 0.01 , at maximum load, and at initial fracture of the unnotched specimens of the titanium is depicted in figure 6 . Each of these increases as the temperature is lowered; the value of each at the temperature of $-196^{\circ} \mathrm{C}$ is more than twice the corresponding value at $+100^{\circ} \mathrm{C}$.

An approximate conformity to linear graphs was obtained for most true strains when the true stresses at a given true strain were plotted to a logarithmic scale against the temperature (fig. 7). These data indicate that the relation between the true stress at a constant true strain, $\sigma_{\delta=\text { constant }}$, and the temperature may be approximately represented by the exponential relationship $\sigma_{\delta=\text { constant }}=A e^{-k T}$, where $T$ is the absolute temperature, and $k$ and $A$ are constant for a given true strain, but vary with the strain of the metal. However, further experimental verification in tension tests on other metals and on other heats of titanium is needed before this relationship can be established as a fundamental rheological relation. It is assumed that this relation would be valid only over a range of temperature in which no major change occurs in the mechanism of deformation.

An apparent change in the mechanism of deformation of the titanium at relatively large true strains during extension at $-196^{\circ} \mathrm{C}$ and to a lesser degree at $-150^{\circ} \mathrm{C}$ was indicated by the reversals in curvature in the rate of work-hardening versus true-strain curves (fig. 4) for $-196^{\circ}$ and $-150^{\circ} \mathrm{C}$. The data points in figure 7 for strains beyond these reversals are connected with the other data points by broken lines. These values were progressively higher with increase in true strain than the values indicated by the apparent exponential relationship.

Rosi and Perkins [3] have reported that commercially pure titanium exhibits strain-aging phenomena at temperatures from $+25^{\circ}$ to $+652^{\circ} \mathrm{C}$, with the maximum degree of strain-aging occurring at about $230^{\circ} \mathrm{C}$. Thus, the occurrence of a small degree of strain-aging of the titanium was to be expected during the initial stages of the deformation 


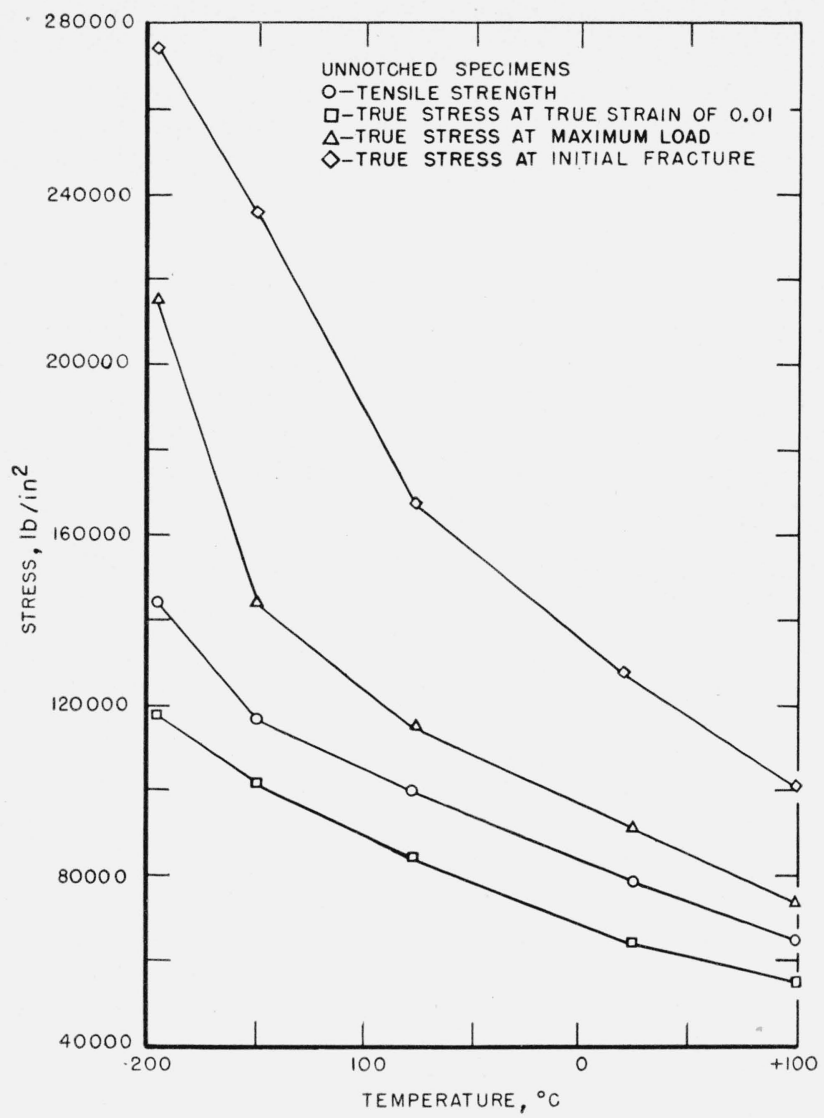

FIGURE 6. Effect of temperature on various tensile properties of unnotched specimens of the titanium.

of the specimen extended in tension at $+100^{\circ} \mathrm{C}$ in the present investigation. The effect of strain-aging and the accompanying change in the mechanism of deformation is revealed by slightly higher true-stress values at true strains of 0.02 to 0.05 than those conforming to the linear graphs (fig. 7).

The change in ductility of the unnotched specimens of the titanium with temperature is shown in figure 8 . The ductility at maximum load and at fracture generally increased with decrease in temperature. The reduction in area at maximum load for specimens extended at temperatures of $+100^{\circ},+24^{\circ}$, and $-78^{\circ} \mathrm{C}$ did not vary greatly. However, it increased greatly as the tempeature was lowered below $-78^{\circ}$ $\mathrm{C}$, and at $-196^{\circ} \mathrm{C}$ it was about three times as great as that at $+100^{\circ} \mathrm{C}$. On the other hand, an appreciable decrease in the reduction of area was observed as the tempeature was lowered from $-150^{\circ}$ to $-196^{\circ} \mathrm{C}$, due to the relatively small amount of deformation that accompanied the necking of the specimen. Thus, lowering the temperature from $-78^{\circ}$ to $-150^{\circ}$ or $-196^{\circ} \mathrm{C}$ greatly increased the ductility of the titanium when subjected to uniaxial tension, whereas lowering the temperature from $-150^{\circ}$ to $-196^{\circ} \mathrm{C}$ reduced the ductility of the

${ }^{7}$ As used in this paper, a transition-temperature range for the tensile specimens indicates a range of temperature over which the ductility of the metal decreases continuously at a relatively rapid rate as the temperature is lowered.

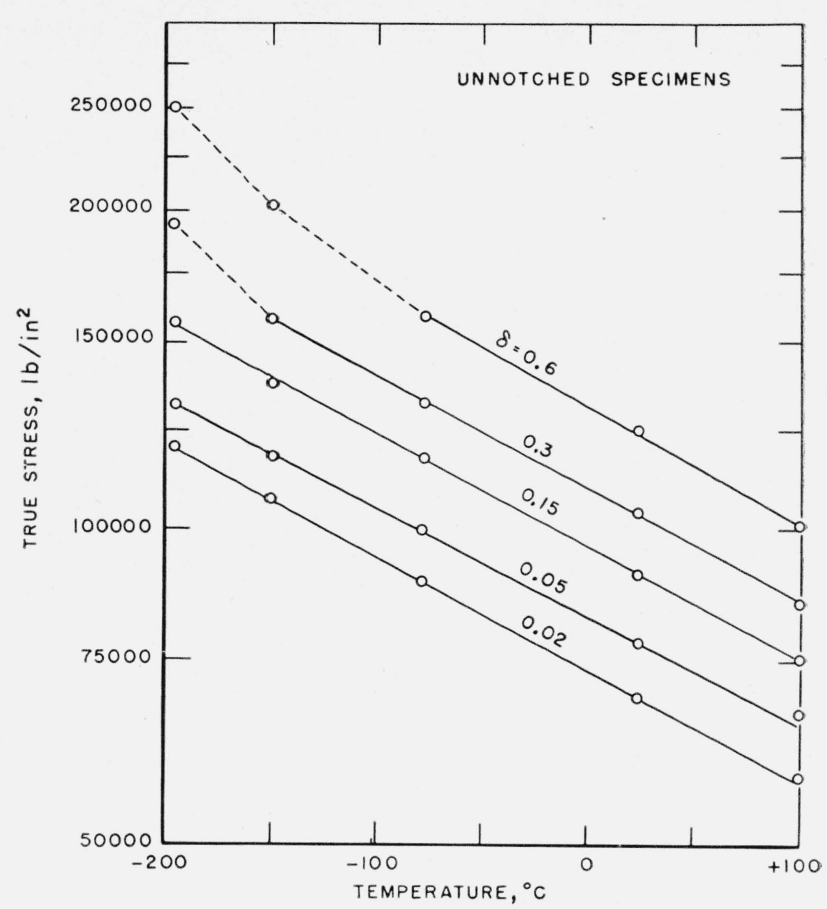

Figure 7. Effect of temperature on the true stress (logarithmic scale) at selected true strains in tension tests made on unnotched specimens of the titanium.

titanium when subjected to moderate multiaxial stresses, such as those induced by the necking of the specimen. The temperature of $-196^{\circ} \mathrm{C}$ apparently was within a transition-temperature range ${ }^{7}$ for the titanium when subjected to these multiaxial stresses. The necked section of the specimen may be considered as a relatively shallow and large-angle notch. The transition-temperature range is expected to rise with an increase in the depth and sharpness of the notch. This effect is discussed in more detail in connection with the results obtained on notched specimens.

The data obtained in the present investigation, exhibiting a general increase in the ductility of the titanium as the temperature is lowered, does not conform to trends reported in some other investigations $[1,2,3]$ on the tensile properties of unnotched specimens of commercially pure titanium; in those investigations a general decrease in ductility with lowering of the temperature was reported. Some data representative of those reported by Rosi and Perkins [3] are also presented in figure 8. This difference in the effect of the temperature on the behavior of the two different heats of titanium may largely be due to differences in the impurities, especially in the amount of nitrogen and hydrogen. The nitrogen content of the heat used by Rosi and Perkins was reported as 0.08 percent, whereas that of the heat used in the present investigation is 0.02 percent. Moreover, the hydrogen content of the latter was very low, being only 0.0065 percent. Studies of the influence of the elements, carbon, oxygen, and nitrogen on the tensile properties of high-purity titanium $[8,9]$ have indicated that 


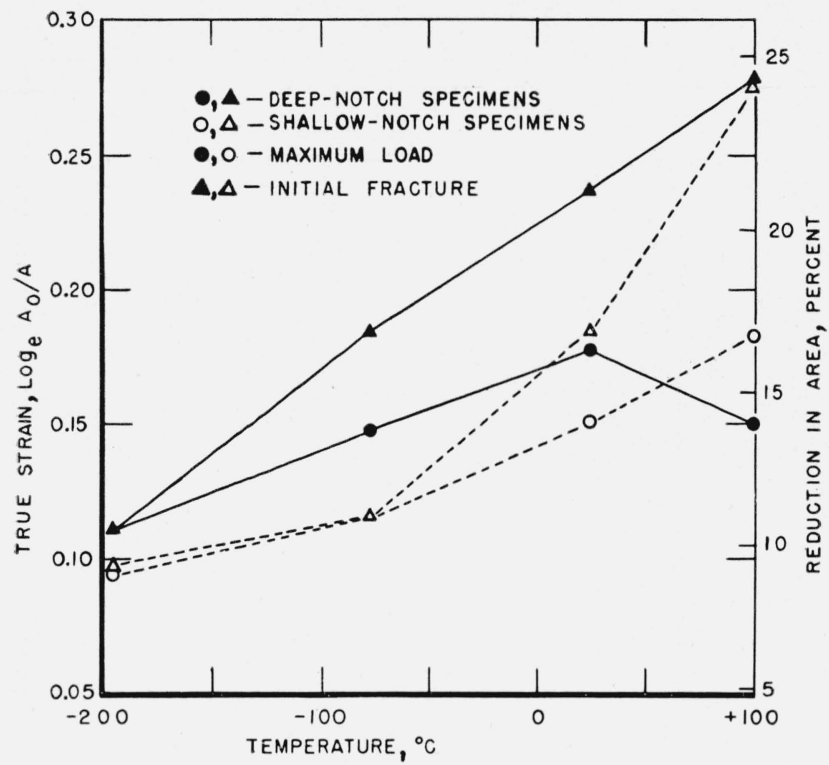

FIgURE 8. Effect of temperature on various ductility indices for unnotched tensile specimens from two different heats of annealed commercially pure titanium.

nitrogen is the most effective of these elements in decreasing the ductility of the high-purity metal at room temperature. Thus, it appears reasonable to expect that an increase in the nitrogen content of commercially pure titanium would decrease the ductility and raise the transition-temperature range of the metal.

\section{c. Influence of Prior-Strain-Temperature History on True-Stress-} True-Strain Relations

Specimens of commercially pure titanium were extended in two-stage tensile tests to reveal the effect of prior-strain-temperature history on the tensile properties and deformation characteristics of the metal. Only three specimens were available for these tests. The true-stress-true-strain data obtained in this study are summarized in figure 9 .

One specimen was extended in the first stage of test at $+24^{\circ} \mathrm{C}$ to a true strain $(0.15)$ just beyond that at the maximum load and subsequently extended to fracture in the second stage of test at $-196^{\circ} \mathrm{C}$. The curve for the second stage of this test lies considerably below that for a single-stage test at $-196^{\circ} \mathrm{C}$. The work-hardening of the specimen during the first stage of extension at $+24^{\circ} \mathrm{C}$ was much less than that of a specimen extended to the same true strain at $-196^{\circ} \mathrm{C}$ in a single-stage test. It should be noted that, although the specimen had been loaded slightly beyond the maximum load in the first stage of test at $+24^{\circ} \mathrm{C}$, the maximum load in the second stage of test at $-196^{\circ} \mathrm{C}$ was only attained after an additional true strain of 0.32 (total true strain of 0.47 ). Moreover, the total true strain to fracture $(0.92)$ was considerably greater than that $(0.78)$ of a specimen extended at $-196^{\circ} \mathrm{C}$ in a single-stage tension test.

The second specimen was extended in the first stage of test at $-196^{\circ} \mathrm{C}$ to a true strain (0.45)

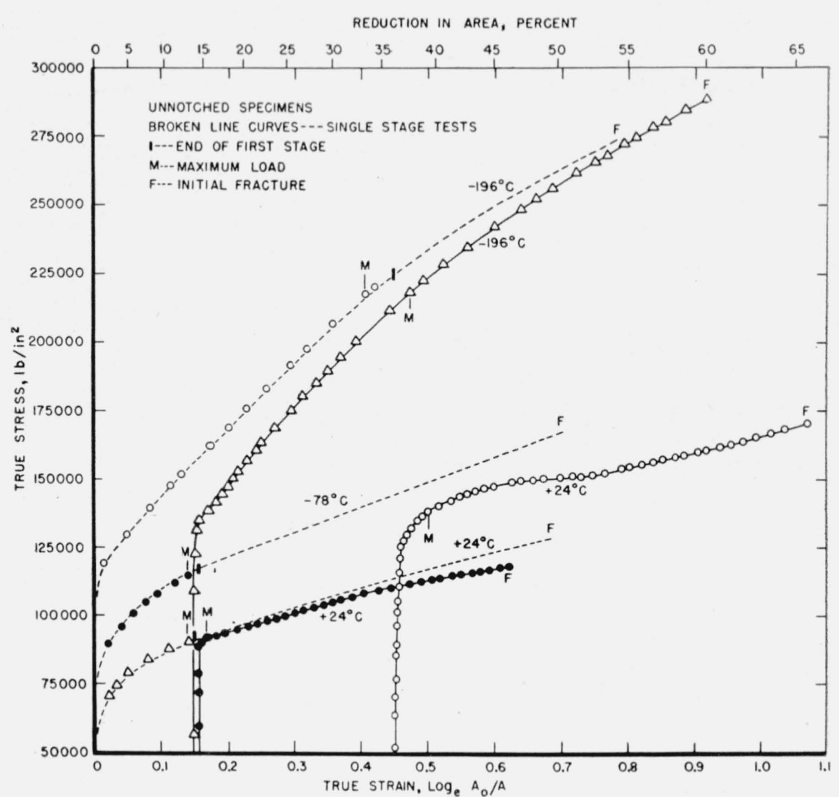

FIGURE 9. True-stress-true-strain graphs for two-stage tension tests made at indicated temperatures on unnotched specimens of the titanium.

slightly greater than that at the maximum load, and then extended to fracture in the second stage of test at $+24^{\circ} \mathrm{C}$. The curve for the second stage of this test lies considerably above the curve for a single-stage test at $+24^{\circ} \mathrm{C}$. This clearly reveals the effects of structural changes and the greater rates of work-hardening at $-196^{\circ} \mathrm{C}$ than at $+24^{\circ} \mathrm{C}$. The total true strain of this specimen (1.07) was much greater than that $(0.69)$ of a specimen extended to fracture at $+24^{\circ} \mathrm{C}$ in a single-stage tension test. Moreover, the true stress at initial fracture of this specimen was about 33 percent greater than that of a specimen extended in a single-stage test at $+24^{\circ} \mathrm{C}$, (170,000 and $128,000 \mathrm{lb} / \mathrm{in}^{2}$, respectively).

The third specimen was extended in the first stage of test at $-78^{\circ} \mathrm{C}$ to a true strain $(0.15)$ slightly greater than that at the maximum load, and then extended to fracture in the second stage of test at $+24^{\circ} \mathrm{C}$. The curve for the second stage of this test lies close to that for a single-stage test at $+24^{\circ} \mathrm{C}$. This indicates that the structural changes and workhardening during the extension in the first stage of test at $-78^{\circ} \mathrm{C}$ were approximately similar to those occurring during the corresponding extension of a specimen at $+24^{\circ} \mathrm{C}$.

\subsection{Tensile Tests on Notched Specimens}

\section{a. True-Stress-True-Strain Relations and Work-Hardening} Characteristics

The true-stress-true-strain relations obtained for single-stage tension tests at $-196^{\circ},-78^{\circ},+24^{\circ}$, and $+100^{\circ} \mathrm{C}$ on the circumferentially notched specimens of circular cross section are presented in figure 10. Three of the main features exhibited in these data are (1) the relatively small true strains to initial fracture of the notched specimens as compared to 


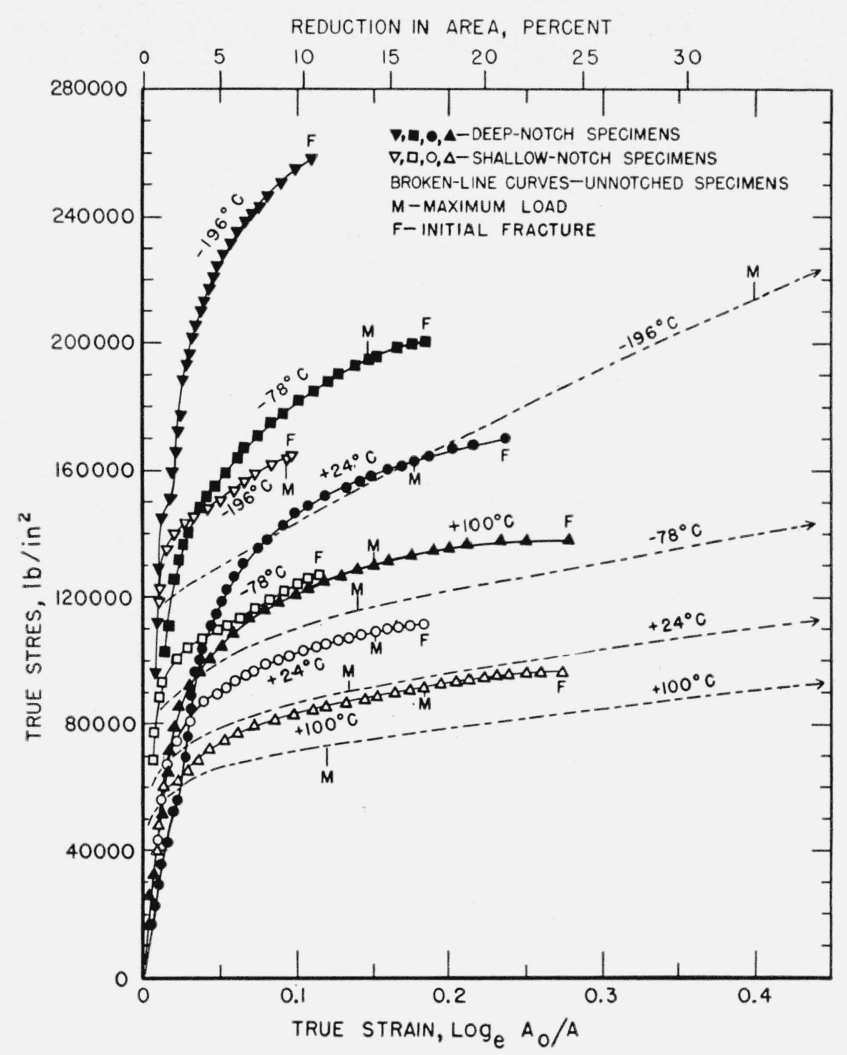

FIgURE 10. True-stress-true-strain graphs for tension tests made at various temperatures on notched specimens of the titanium.

those for unnotched specimens (fig. 2), (2) the elevation of the true-stress-true-strain curves for the notched specimens, and especially those for the deep-notch specimens, above those for the unnotched specimens at the corresponding temperatures, and (3) the decrease in the ductility of both series of notch specimens with decrease in the temperature.

The relatively small ductility (true strain at initial fracture) of notched tensile specimens is usually attributed to the effects on the metal of (1) the multiaxial stresses induced by the notch geometry, and (2) the stress concentrations at the root of the notch and the resulting stress gradients across the minimum cross section of the specimen.

The stress concentrations and stress gradients across the minimum cross section vary with the geometry of a notched specimen. For specimens with a constant notch angle and a constant radius at the root of the notch, the stress concentrations and stress gradients are generally believed to decrease with increase in the depth of the notch, except for very shallow notches. Thus, since the ductility increases with decrease in stress concentrations and stress gradients, the ductility of the deepnotch specimens should be greater than that of the shallow-notch specimens. However, the ductility of metal is also lowered when subjected to multiaxial stresses such as those induced by the notch, and for specimens with a constant notch

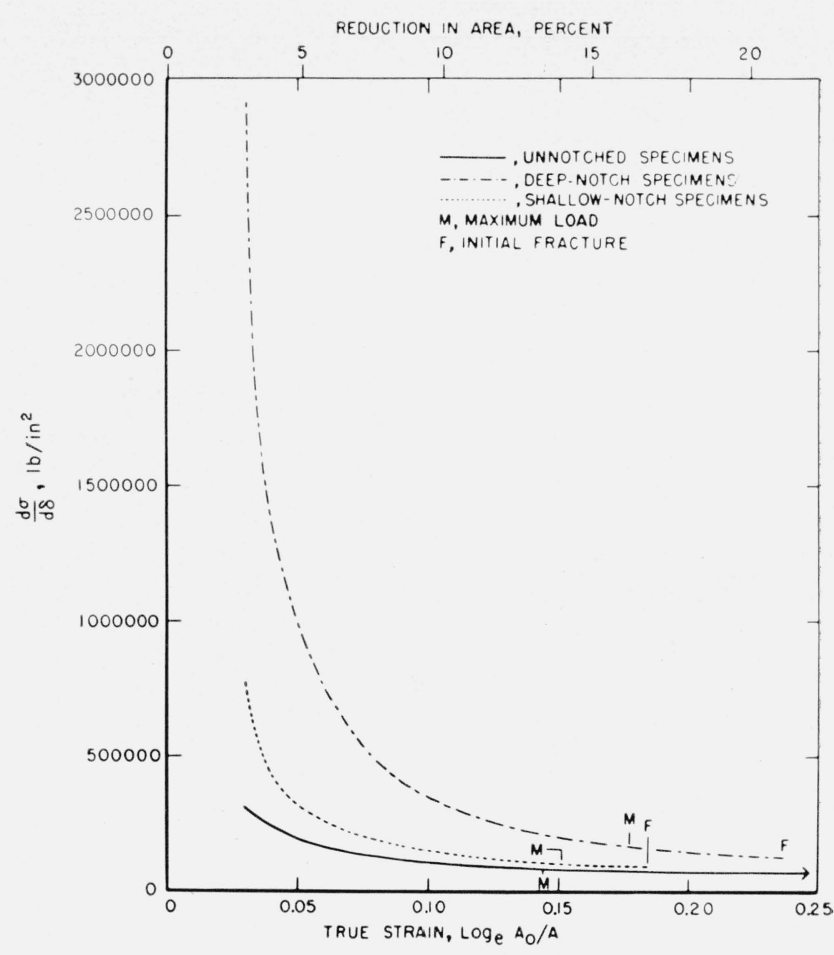

FIGURE 11. Variation of the rate of work-hardening with true strain of notched and unnotched specimens of the titanium in tension tests made at room temperature.

angle and a constant radius at the root of the notch, the ductility tends to decrease with increase in the depth of the notch due to the effect of the multiaxial stresses.

The true strain at initial fracture of each deepnotch specimen was considerably greater than that of the shallow-notch specimen extended at the same temperatures. These data indicate that the effect of the stress concentrations and stress gradients on the ductility of this heat of titanium was greater than that of the multiaxial stress state.

The resistance of the titanium to tensile deformation was greater when the metal was subjected to multiaxial stresses such as those induced by the notches than when it was subjected to uniaxial tension. This is clearly illustrated in the truestress-true-strain curves in figure 10, by the moderate and high elevations, respectively, of the curves for the shallow-notch and deep-notch specimens above that for the unnotched specimen extended to fracture at the same temperature.

The rate of work-hardening of the titanium during deformation in tension depends greatly upon the stress system. This is shown clearly in figure 11 , which depicts the variation in the rates of workhardening with true strain for notched and unnotched specimens deformed in tension at $+24^{\circ} \mathrm{C}$. At small true strains (0.03 to 0.05 ), the rate of workhardening of the deep-notch specimen was 5 to 10 times as great as that for the unnotched specimen, whereas the rate of work-hardening of the shallownotch 'specimen over the same strain range was only 
about twice that of the unnotched specimen. The relative differences between the rates of work-hardening of these specimens decreased with increase in strain. Similar relationships were observed for the specimens tested at $-196^{\circ},-78^{\circ}$, and $+100^{\circ} \mathrm{C}$.

It may be suggested that deformation in tension, under a multiaxial stress system, such as that induced by the notch, occurs by the movement of dislocations on slip planes in a greater number of directions within the crystals than is the case for deformation under uniaxial tension. Thus, with deformation under the multiaxial stress system, there will be a large number of intersections of dislocations with the accompanying production of jogs in the dislocations. Energy is required to make one dislocation move across another dislocation. Moreover, the energy required to move a dislocation with a jog is generally greater than that needed to move the dislocation prior to the acquisition of the jog. Both of these factors tend to increase the work-hardening of the metal [10].

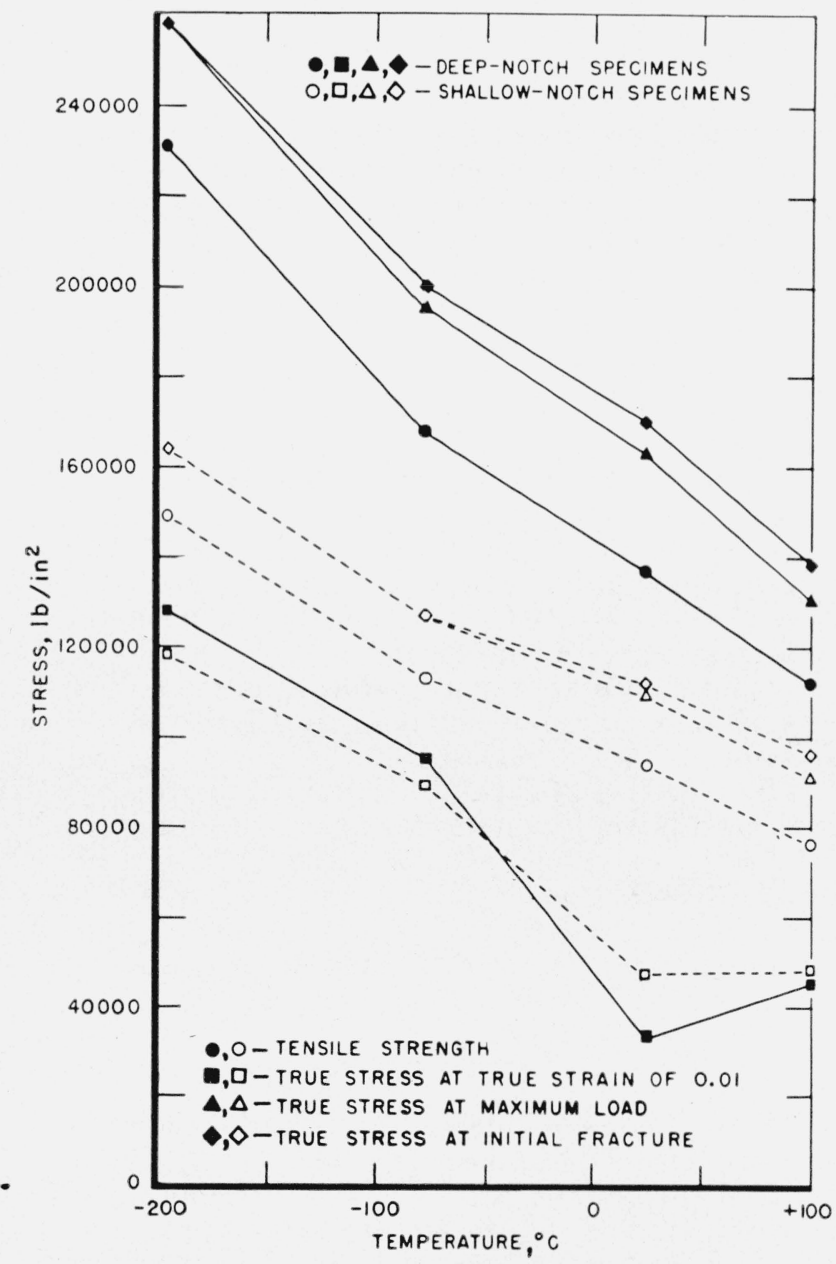

FIGURE 12. Effect of temperature on various tensile properties of notched specimens of the titanium.

\section{b. Influence of Temperature on Tensile Properties}

The relations between the temperature and some of the strength indices of both the shallow-notch and the deep-notch specimens of the titanium are presented in figure 12. In general, these strength indices increase greatly with lowering of the temperature within the range $+100^{\circ}$ to $-196^{\circ} \mathrm{C}$. Moreover, the increase in strength of the deep-notch specimens is greater than that of the shallow-notch specimens. It should be pointed out, however, that the increase in the values of the true stress at a true strain of 0.01 with decrease in temperature should be considered as only a general trend; these values were affected greatly by the degree of local deformation that occurred at very low stresses in the region of high stress concentration at the root of the notch. This localized deformation was much greater in the specimens extended at $+24^{\circ}$ and $+100^{\circ} \mathrm{C}$ than in those extended at $-78^{\circ}$ and $-196^{\circ} \mathrm{C}$.

The relations between temperature and ductility (true strain at maximum load and true strain at initial fracture) for the notched specimens are shown in figure 13. The true strains at initial fracture of both the shallow-notch and the deep-notch specimens decrease with a lowering of the temperature. A similar trend is observed in the data for the true strain at maximum load, except that for the deepnotch specimens the true strain was less at $+100^{\circ}$ that at $+24^{\circ} \mathrm{C}$.

The general decrease in the ductility of the notched tensile specimens with decrease in temperature indicates that the range $+100^{\circ}$ to $-196^{\circ} \mathrm{C}$ is within the transition temperature range, for the

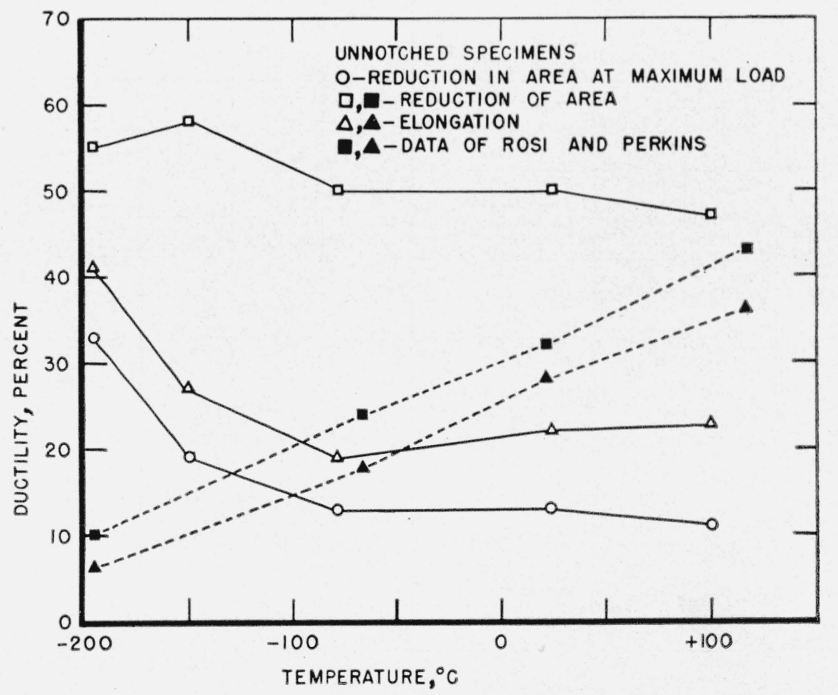

FIGURE 13. Effect of temperature on the true strains at maximum load and at initial fracture of notched tensile specimens of the titanium. 
titanium deformed slowly in tension under the multiaxial stress systems and stress concentrations induced by both the shallow and the deep notches. Thus, this transition-temperature range is considerably higher than that obtained on the titanium deformed slowly in tension under uniaxial stress; the transition-temperature range of the latter was apparently below $-196^{\circ} \mathrm{C}$.

\subsection{Impact Tests on Charpy V-Notch Specimens}

In is known that increasing the rate of deformation of a metal that exhibits a transition-temperature range generally raises this range. The influence of a high rate of deformation on the transition-temperature range of the titanium, subjected to multiaxial stresses, was studied by making impact tests at $-196^{\circ}$ to $+300^{\circ} \mathrm{C}$ on Charpy V-notch specimens. These data are summarized in figure 14. A transition temperature, based on the mean value of the energy absorbed at the lowest and the highest temperatures, of about $+150^{\circ} \mathrm{C}$ was obtained. The energy values decreased greatly as the temperature was lowered through the range $+300^{\circ}$ to $+26^{\circ}$ $\mathrm{C}$; the decrease in energy with lowering of the temperature below $+26^{\circ} \mathrm{C}$ was relatively small. The energy absorbed in fracturing the specimens at the lowest temperature, i. e., at $-196^{\circ} \mathrm{C}$, was about $10 \mathrm{ft}-\mathrm{lb}$. This indicates that the titanium still retains appreciable notch toughness even at very low temperatures.

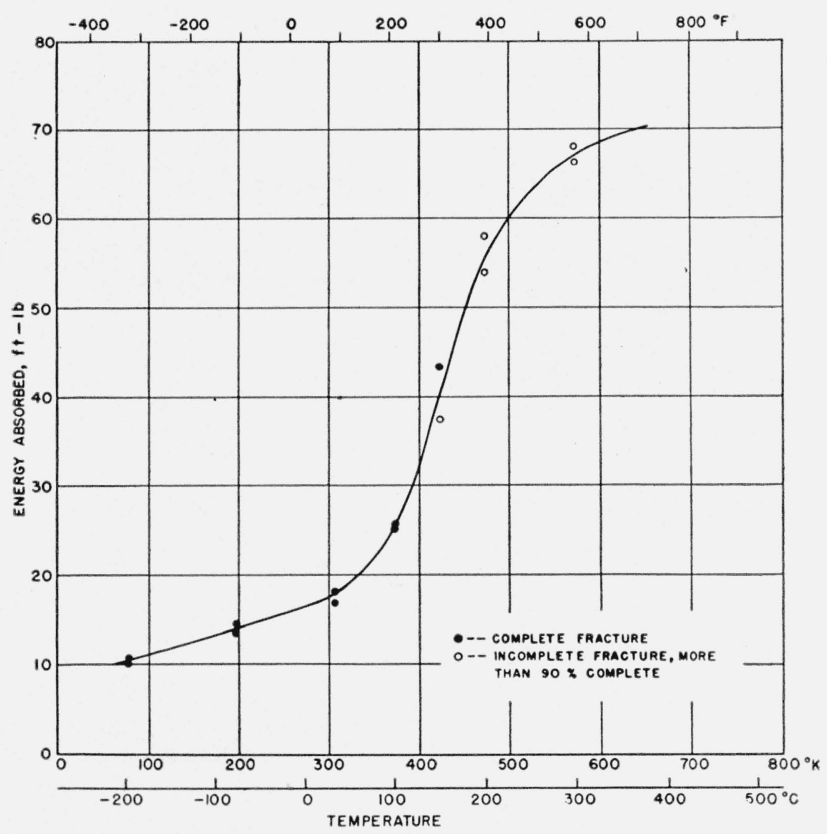

FIGURE 14. Relation of temperature to the energy absorbed in "fracturing Charpy V-notch specimens of the titanium.

\section{Summary and Conclusions}

The strengths and the rates of work-hardening of both notched and unnotched tensile specimens of annealed commercially pure titanium generally increased as the temperature was lowered within the range $+100^{\circ}$ to $-196^{\circ} \mathrm{C}$. The presence of multiaxial stresses induced by the notch increased both the strength and the rate of work-hardening of the titanium. These effects were much greater in the deep-notch specimens than in the shallow-notch specimens.

The ductility of the titanium extended under uniaxial stress was not impaired by lowering of the temperature within the range $+100^{\circ}$ to $-196^{\circ} \mathrm{C}$. The truestrain at maximum load was increased greatly as the temperature was lowered from $-78^{\circ}$ to $-150^{\circ}$ and $-196^{\circ} \mathrm{C}$.

The ductility of the notched tensile specimens of the titanium was much less than that of the unnotched specimens. The ductility of the titanium was reduced greatly by the presence of multiaxial stresses, stress concentrations, and stress gradients in the notched specimens. The ductility of the shallow-notch specimens was less than that of the deep-notch specimens, apparently due to the higher stress concentrations and stress gradients in the former specimens. Moreover, the experimental data obtained in this study indicate that the influence of the multiaxial stress system induced by the notch in reducing the ductility of the titanium is less than that due to the stress concentrations and stress gradients.

The experimental results indicate that the transition-temperature ranges for the titanium vary greatly with the stress system and the rate of deformation. The transition-temperature range was below $-196^{\circ} \mathrm{C}$ for slow deformation under uniaxial stress, apparently between $-196^{\circ} \mathrm{C}$ (or perhaps lower) and $+100^{\circ} \mathrm{C}$ for slow deformation under multiaxial stresses, and between $+26^{\circ}$ and $+300^{\circ} \mathrm{C}$ for rapid deformation under multiaxial stresses characteristic of the impact test on Charpy V-notch specimens.

The experimental results obtained in this study indicate that in designing for use of titanium at low temperatures, special attention should be placed (1) on the elimination or minimization of sharp fillets and small radii at roots of reentrant angles, and (2) on providing protection against the acquisition of nicks or deep scratches during service.

The authors are indebted to the Chemistry Division for chemical and spectrochemical analyses, to D. I. Walter of the Naval Research Laboratory for ${ }^{*}$ the oxygen and hydrogen determinations, and to C. R. Johnson for assistance in the experimental investigation. 


\section{References}

[1] J. W. Spretnak, M. G. Fontana, and H. E. Brooks, Notched and unnotched tensile and fatigue properties of ten engineering alloys at $25^{\circ}$ and $-196^{\circ} \mathrm{C}$, Trans. Am. Soc. Metals 43, 547 (1951).

[2] M. G. Fontana, S. M. Bishop, and J. W. Spretnak, Investigation of mechanical properties and physical metallurgy of aircraft alloys at very low temperature, pt. V, A. F. Tech Rep 5662 (1953).

[3] F. D. Rosi and F. C. Perkins, Mechanical properties and strain aging effects in titanium, Trans. Am. Soc. Metals 45, 972 (1953).

[4] D. I. Walter, Determination of oxygen in titanium, Anal. Chem. 22, 297 (1950)

[5] G. W. Geil and N. L. Carwile, A reduction-of-area gage for use at low temperatures, J. Research NBS 43, 527 (1949) RP2044.
[6] G. W. Geil and N. L. Carwile, Tensile properties of ingot iron at low temperatures, J. Research NBS 45, 129 (1950) RP2119.

[7] G. W. Geil and N. L. Carwile, Tensile properties of copper, nickel and some copper-nickel alloys at low temperatures, NBS Circular 520, p. 67 (1952).

[8] W. L. Finley and J. A. Snyder, Effect of three interstitial solutes (nitrogen, oxygen, and carbon) on the mechanical properties of high-purity alpha titanium, Trans. Am. Inst. Mining Met. Engrs. 188, 277 (1950)

[9] R. I. Jaffee, H. R. Ogden, and D. J. Maykuth, Alloys of titanium with carbon, oxygen, and nitrogen, Trans. Am. Inst. Mining Met. Engrs. 188, 1261 (1950).

[10] W. T. Read, Jr., Dislocations in crystals (MeGraw-Hill Book Co., Inc., New York, N. Y., 1953).

Washington, August 13, 1954. 